\title{
REFLEXÕES SOBRE A VERDADE
}

Saul Goldenberg *

*Editor Chefe Acta Cirúrgica Brasileira

A verdade: o que é e onde se encontra ? ${ }^{1}$

DESDE QUE ARISTÓTELES QUESTIONOU O QUE
SERIA
"A VERDADE”,
MUITAS MENTES BRILHANTES TÊM TENTADO
DEFINI-LA;
LAMENTAVELMENTE SEM O LOGRAR.

Ao tratar do tema, não temos a pretensão de cobri-lo por inteiro. $\mathrm{O}$ assunto é complexo e tão antigo quanto a própria criação do ser humano.

\section{O QUE É A VERDADE ?}

Existiria uma verdade única, intangível e absoluta ?

A MEDICINA É A CIÊNCIA DAS VERDADES TRANSITÓRIAS MUITAS VEZES TRANSFORMADAS EM DOGMAS PARA FINS DIDÁTICOS.

Muitas das verdades e condutas adotadas no passado revelaram-se com o tempo em inverdades. Muitos estômagos foram ressecados e nervos vagos seccionados para tratamento de úlceras pépticas e muitos baços foram extirpados no dogma "baço lesado é baço extirpado". Outra verdade de outrora e que se tornou mentira: “Grandes incisões, grandes cirurgiões".

Há uma corrente de pensamento que sustenta não haver nenhuma verdade além daquilo que é perceptível aos órgãos sensoriais.

A "verdade" é a realidade como ela é.

Verdade é tudo que se manifesta aos olhos do corpo e do espírito. Verdade é a manifestação de tudo o que é ou existe tal como é. Se ao comer certo alimento, percebermos que é amargo ou doce, o gosto do alimento deixa de ser suposição, torna-se uma certeza. E, se virmos que a cor de uma flor é vermelha, não caberá dúvidas quanto à sua coloração ${ }^{1}$.

Outra corrente de pensamento, no entanto, advoga que cada um tem sua própria verdade, não existindo, portanto, a verdade única. Não há percepções $\mathrm{e}$ sensações uniformes. Estas diferem de ser para ser e de situação para situação.
As religiões defendem a existência de uma verdade única e absoluta. D'us é a verdade ${ }^{1}$.

\section{A VERDADE É OU NÃO É. \\ O “Houaiss” dicionário da Língua Portuguesa², define:}

Verdade, propriedade de estar conforme com os fatos ou a realidade; exatidão, autenticidade, veracidade

1.1 a fidelidade de uma representação em relação ao modelo ou original; exatidão, rigor, precisão. Ex.: a verdade de um quadro, de uma foto

2 Derivação: por extensão de sentido. coisa, fato ou evento real, verdadeiro, certo

Ex.: o que eu contei corresponde à v.

3 Derivação: por extensão de sentido. qualquer idéia, proposição, princípio ou julgamento que se aceita como autêntico, digno de fé; axioma, máxima

Ex.: as v. de uma religião, de uma filosofia

4 Derivação: por extensão de sentido. procedimento sincero, retidão ou pureza de intenções; boa-fé

A "propriedade de estar conforme com os fatos ou a realidade" é bastante complicado, já que determinar o que é ou não "real” não é tarefa simples.

O que é real para uns, pode não ser para outros.

Alguém está sentindo uma grande dor, essa percepção da dor é certamente claríssima nele [VERDADE], mas outro pode pensar que ele está simulando, ludibriando, iludindo [MENTIRA]. Como provar com quem está a verdade ?

Como distinguir o que é real ? Como separar o fato concreto da opinião subjetiva; como distinguir aquilo que é real, "de verdade”, daquilo que é apenas fruto de uma visão pessoal ou da crença de um determinado grupo de pessoas?

O pensamento cartesiano nos recomenda fugir do SUBJETIVISMO e ter a obsessão da dúvida. Duvidar é pensar. A busca pela verdade calcada na investigação científica e que deve permanecer em nós.

A dúvida: onde estamos errando ou faltando com a verdade ? A causa do erro, "que apenas testemunha haver imperfeição em [nós]”. Descartes compreende o erro como 
uma privação de algum conhecimento que dever-se-ia possuir, mas que não se possui.

\section{Como se posicionar frente as "verdades biológicas", mutáveis, alteráveis por natureza.}

A recomendação é desenvolver a capacidade de exercer a CRÍTICA. Cultivar a arte e a habilidade de julgar o fato, desenvolver o exame racional, indiferente a preconceitos, convenções ou dogmas. Examinar e avaliar minuciosamente toda informação científica. Desenvolver a capacidade de julgar com juízo crítico.

Aplicar o método científico e procurar as evidências baseadas em pesquisas.

O método científico é um conjunto de regras básicas para o desenvolvimento de uma experiência a fim de produzir conhecimento e juntar evidências mensuráveis, sendo imparcial na interpretação dos resultados.

Sempre que possível testar em laboratório as “verdades biológicas vigentes”. Contudo, os trabalhos realizados com animais de experimentação nem sempre apresentam rigor metodológico. Nos artigos de investigação científica a quantidade e a qualidade da amostragem é pouca elucidativa podendo suscitar dúvidas sobre sua credibilidade. Nos trabalhos experimentais, habitualmente, é pouca a descrição dos animais utilizados. Muitos artigos não mencionam a origem dos animais e como eles estão sendo mantidos.Não raro a credibilidade da qualidade da amostra é duvidosa. Existe grande variedade de respostas a diferentes estímulos entre as espécies. Qual a causa deste descuido ? Muitas vezes por insuficiência de conhecimento no uso e no manejo de animais de experimentação. Torna-se imperioso a ministração de cursos sobre bioterismo.

Não se erra por que se quer. Não se sabe que está errando ou sendo inexato e, portanto, faltando com a verdade.

Outro aspecto é o cuidado com as inverdades da “propaganda enganosa”. ALERTA para as novidades, modismos, muito freqüentes em medicina. Evitar condutas e procedimentos sem estarem consagrados pelo conhecimento e pelo uso aprovado.

Como editor de revista científica pergunto-me sempre:

\section{Como ficar convencido da veracidade de um artigo científico ?}

\section{Como discernir o verdadeiro do falso ?}

Obviamente torna-se imperioso considerar o autor e os co-autores. Como seres humanos eles são totalmente heterogêneos. Existem os disciplinados e lamentavelmente os indisciplinados. Os de boa formação e os de "má formação congênita”. Os que mostram ser de boa escola e os que não tem orientação metodológica científica.

Como CONFIAR na seriedade da pesquisa e das citações bibliográficas, da amostragem e dos procedimentos, do planejamento e do tratamento estatístico e a confiabilidade dos resultados?

São todos de NÍVEL SUPERIOR, de nível universitário, mas a dignidade, o mérito e a qualidade deste nível variam nos autores. Daí a imensa importância da avaliação pelos pares e pelo corpo editorial da revista.

Afinal, o que é Verdade e como a reconhecer?

O fato é que a verdade é frágil e poderosa na ciência biológica.

Frágil porque é efêmera, portanto precária.

Poderosa porque tem grande influência, enquanto vigente.

\section{Referência}

1. Cohen A. A verdade: o que é e onde se encontra? Morashá. 2007;14:6-10.

2. Houaiss A, Villar MS, Franco FMM. Dicionário Houaiss da língua portuguesa. Rio de Janeiro: Objetiva; 2001. Verdade; p. 2845. 